\title{
Causes and remedial measures for rockfall and landslides in Naini lake basin: Uttarakhand, India
}

\author{
Singh Kanchan ${ }^{1}$ and Singh M.P. ${ }^{2}$ 的
}

Received: 06.03.2020

Revised: 04.04.2020

Accepted: 17.04.2020

\begin{abstract}
The history of Naini Lake Basin reveals that this beautiful scenic natural surrounding has been a victim of landslides, mass erosion, rock-fall and slumping. Its location in highest rainfall zone, weak lithology and topography are the obvious reasons for these activities. Moreover the rising anthropogenic interferences like construction activities and deforestation on this geo-dynamically unstable zone has added more to the problem. The manuscript accounts of incidences of landslide and erosion activities, their causes and effects afterwards. An effort to stratify and to mark the comparatively lesser stable zones and patches in and around the lake basin has been made to demarcate the risk prone belt. Adequate measures for environmental planning and proper implementation of such plans are the utmost need of the hour to safeguard not only the beautiful basin but also the olives and property of population living under the continuous threat of disaster.
\end{abstract}

Key Words: anthropogenic, erosion, landslide, rainfall, rockfall, slopes

\section{Introduction}

The frequency of landslides in the Kumaon Lesser Himalayas varies from area to area, depending on anthropogenic changes taking place and the underlying structure. The Pre-Cambrian sedimentary and metamorphic rocks of the lesser Himalaya have experienced severe folding, faulting and shattering during successive phases of the Himalayan Orogeny. Neo-tectonic activity has accelerated the pace of the erosion. The subtropical intense rainfall is responsible for the formation of a thick mantle of weathered rocks. Extensive human activities related to construction of roads etc. have intensified erosion and triggered slope failures on the highly unstable rocks in the region. (Bartarya and Valdiya 1989; Gupta et al. 2016; Martin et al. 1989). The tectonic and physiographic character of this area adds to the threat of environmental havoc like landslides, erosion and slumping (Kotlia, et al. 2001). The history of landslides dates back to 1867, 1880, 1898, 1939, 1942, and 1958. Moreover anthropogenic interferences on the natural surroundings have increased the hillside instability at an alarming rate. Author's Address

${ }^{1}$ Department of Geography, SDM Govt PG College, Doiwala, Dehradun

${ }^{2}$ Graphic Era Deemed to be university, Clement town, Dehradun

E-mail.: dmps96@gmail.com
It is evident from the increased frequency of landslides in the recent years, i.e, 1987, 1988, 1991,1993, 1996 and 2001. Some parts of the basin are still facing such hazards even during the present times. In this way, the entire natural landscape in the around Naini Tal together with a total of thirty two- thousand residents always lives under permanent threat of landslide and rock-fall, which is often aggravated in the rainy season. Therefore, immediate measures have to be taken and proper planning is necessary to overcome such terrific situations in the future. Such efforts should identify and work out the past and existing frequency of landslides and erosion activity. This will help in not only preserving the natural surroundings of Nainital but also in saving human lives. Frooks et al. (1985) provided adequate measures towards prevention by the identification of sites of especially high landslide hazards and the definition of areas that may be capable of geotectonic stabilization.

The table given ahead (Table 1) records the history of landslides in Naini Lake Basin and its adjoining areas, along the geological structure of the localities and their overall impact on the landscape as well as life and property in affected areas. 
Area under study: The Lake Basin of Nainital is situated at an altitude of $1938 \mathrm{~m}$ along the southern sections of Kumaon Lesser Himalaya, and lies at $29^{\prime} 00$ to $29^{\prime} 05^{\prime}$ North Latitudes and $8014^{\prime}$ to $78^{\prime} 80$ East Longitudes, in Uttarakhand State (Fig. 1). It has more or less a peripheral location with the Himalayan area lying to its north and has grown around a magnificent fresh water lake. The settlement of the town extends across the slopes over an area of 11.73 sq.km.

The lake and its immediate surroundings altogether have formed a famous tourist resort in this zone of Himalaya owing not only to the beautiful natural setting but also to its easily accessible location and transport connections from many big towns of Northern India including the capital of the country.

Data base for the study: The data and information used in this study have been taken from various published and unpublished sources. Field data and quantitative and qualitative information have also been collected by focusing on the land slide affected areas.

\section{Landslides and relational factors}

The occurrence and frequency of land slide and rock fall activities have dire relationship with certain factors including natural and human. Presented ahead is a brief account on relationship between landslide and these factors.

\section{Landslides and Lithology}

The Naini lake occupies a high altitude valley lying NW-SE. The lake is surrounded, by three lithostrategraphic units of the Krol Nappe. The first Naini Deopatta, second the Sher-ka-danda and Snow-view ridges and the third Ayarpatta ridge. The first two, which border the Lake Basin on the north and west, are composed of the shales and marls of the lower Krol. A major fault including the Naini Tal fault separates the basin from the Ayarpatta ridge on the sourth-west. This unit is composed mainly of limestone, dolomites, subordinate blanck shales, and sandstone of the upper Krol. A smaller part of the Ayarpatta ridge area is also composed of red shales and marls of middle Krol. These rocks are characterized by local intra-elasticity, pinch and swell, crossbedding, graded bedding and columnar branching (Valdiya, 1988). The area and spot-wise details are given in (Table. 1). This underground physiography provides a good ground for disturbances like landslides and slumping.

\section{Landslides and Slope}

The slope in the entire region is invariably different and irregular. The average slope of the Lake Basin is $19^{\circ}$ which varies from $47^{\circ}$ at Naina peak to $1^{\circ}$ along the Flats. Comparatively larger portion of the area lies with the slope group of $20^{\circ}$ to $25^{\circ}$. The south-east facing Naina Deopatta ridge is the steepest with a mean slope of $32^{\circ}$. The south-west facing Snow-View ridge has a mean slope of $21^{\circ}$. The slope is straight and is characterized by parallel streams alongwith the fractures and joints. The mean slope of north-east facing Ayarpatta ridge is $18^{\circ}$. The entire Balia ravine slopes with the mean value of $20^{\circ}$ which gradually increases up to $35^{\circ}$ (Rawat, 1988) (Details in table 1). The rainfall and uncontrolled human interference along with the slopes have added greatly to the problem of recurring landslides.

\section{Landslides and Rainfall}

During heavy rainfall and the periods immediately after rains most of the landslides occur. This is evident from the past experiences. Naini Tal basin lies in the zone of highest rainfall in the Kumaon Himalayas and receives over $2500 \mathrm{~mm}$ rains annually. The area is highly susceptible to largescale landslips because the weak lithology along steep slope is not able to bear the heavy water flow. The history of slope failures indicates that most of the landslides have occurred during the months of July, August, and September (Table 1).

\section{Landslides and anthropogenic activities}

Construction of buildings and roads is an abuse on a geo-tectonically fragile area like Nainital landslides are a nightmare for all concerned with new road building (Bansal and Mathur 1976). The pressure of population and its exceedingly rising needs are increasing in the Naini Lake Basin. This has accelerated construction activities, removal of forest cover and indiscriminate slope cutting. In most of the cases, the drainage course is adversely affected by the construction activities along the steep slopes. These human activities, in combination with geomorphic factors result into frequent landslides, soil erosion, slumping and siltation in lake bed and formation of delta at various locations (Fig. 2.).

\section{History of Landslides in Naini Lake Basin and} its vicinity

Practically half of the area of Lake Basin generates mass-movement during each monsoon rains. As a 
Causes and remedial measures for rockfall and landslides

Table 1: Incidence of landslides in Naini Lake Basin induced by high rainfall in combination with slope and lithology

\begin{tabular}{|c|c|c|c|c|c|}
\hline Locality & Date of Event & Rainfall & $\begin{array}{l}\text { Mean } \\
\text { Slope }\end{array}$ & Lithology & Remarks \\
\hline Snow-view & 1867 & $26.29 \mathrm{~cm}$ & $21^{\circ}$ & Shale and marls & $\begin{array}{l}\text { Massive landslip giving rise to the debris fan on which the Naini Tal Club is } \\
\text { situated. }\end{array}$ \\
\hline Snow-view & 18.9 .1880 & $\begin{array}{l}84 \mathrm{~cm}(16 \text { to } 19 \\
\text { Sept.) }\end{array}$ & $21^{\circ}$ & Shale and marls & $\begin{array}{l}143 \text { people killed, much damage to Victoria hotel and pristine Naina Devi } \\
\text { Temple (then located close to Boat House club) and converted the north- } \\
\text { western part of the lake into level tract now known as 'the Flats'. }\end{array}$ \\
\hline Ballia Ravine & 17.8 .1898 & $\begin{array}{l}91 \mathrm{~cm}(9 \text { to } 17 \\
\text { Sept })\end{array}$ & $25^{\circ}$ & Infra Krol Slates & $\begin{array}{l}28 \text { people killed and destroyed many buildings and old Nainital-Ranibagh } \\
\text { Cart road. }\end{array}$ \\
\hline Middle Ayarpatta & 13.7 .1939 & $71.05 \mathrm{~cm}$ & $18^{\circ}$ & Dolomite and Limestone & $\begin{array}{l}\text { Road area was damaged by landslide (An area of } 30 \mathrm{~m} \times 90 \mathrm{~m} \text { was completely } \\
\text { slumped at higher zones of the area. }\end{array}$ \\
\hline $\begin{array}{l}\text { Below Edwinstowe } \\
\text { cottage }\end{array}$ & July 1942 & $117.3 \mathrm{~cm}$ & $18^{\circ}$ & Dolomite and Limestone & $\begin{array}{l}\text { A huge land mass slipped down below Edwinstowe cottage. The landslide } \\
\text { damaged a considerably large slope along Phansi gadhera. }\end{array}$ \\
\hline Phansi Gadhera & 1958 & $67.61 \mathrm{~cm}$ & $12^{\circ}$ & Dolomite and Limestone & $\begin{array}{l}\text { Several buildings were affected and a forest area covered by about } 100 \text { trees } \\
\text { was completely damaged. }\end{array}$ \\
\hline Naina peak & 10.09 .1987 & $53.15 \mathrm{~cm}$ & $32^{\circ}$ & $\begin{array}{l}\text { Grey calcareous slate, } \\
\text { Limestone, in (lower Krol) } \\
\text { and marls inter bedded } \\
\text { with dolomite (Middle } \\
\text { Krol) dolomite and shale }\end{array}$ & $\begin{array}{l}\text { Affected } 61 \text { buildings and about } 470 \text { families. The debris and boulders } \\
\text { slipped down up to Melrose Compound and Brookehill compound. }\end{array}$ \\
\hline Naina peak & 11.03 .1988 & $64.25 \mathrm{~cm}$ & $32^{\circ}$ & Do- (Upper Krol) & Several temporary huts and few permanent buildings were destroyed. \\
\hline Snow-view & 11.09 .1991 & $42.80 \mathrm{~cm}$ & $21^{\circ}$ & Shale and marls & $\begin{array}{l}\text { The upper and lower Mall Road, Staff House area and the dwellings situated } \\
\text { between upper and lower Mall Road were worst affected by continuous } \\
\text { heavy rains leading to cracks and damages. }\end{array}$ \\
\hline Snow-view & $\begin{array}{ll}11.09 .1993 & \text { to } \\
12.09 .1993\end{array}$ & $\begin{array}{l}13.80 \mathrm{~cm} \\
15.3 \mathrm{~cm}\end{array}$ & $21^{\circ}$ & Shale and marls & $\begin{array}{l}\text { One House was completely destroyed. The debris obstructed the water flow } \\
\text { which then overflew from roadsides and slopes causing severe erosion. }\end{array}$ \\
\hline Rais Hotel Area & 12.07 .1996 & $17.7 \mathrm{~cm}$ & $25^{\circ}$ & Infra Krol Slates & $\begin{array}{l}\text { Several temporary residential huts and some permanent houses damaged. } \\
2 \mathrm{df} \text { workers killed and huge land mass slipped down to the cart road to } \\
\text { Birbhatti and R.S.S. School. The area is prone to much loss since it lies on a } \\
\text { deep fault zone. }\end{array}$ \\
\hline Ayarpatta hill & 1998 & $18.3 \mathrm{~cm}$ & $18^{\circ}$ & Dolomite and Limestone & \\
\hline
\end{tabular}




\section{Singh Kanchan}

matter of fact the entire north-western part of the town is located on a succession of landslides originated from the Naina peak and Snow-view ridge.

The history of landslides in this region dates back to the year 1867 and 1880. The landslides of 1867 gave rise to the debris fan on which the Nainital club is presently situated. After 13 years adjacent slope of Naina-peak failed disastrously on $18^{\text {th }}$ September 1880. Event of less than half a minute duration that took a toll of 143 lives in the upper part of township of Nainital was largely a debris avalanche. It swept away Victoria Hotel, some buildings and the ancient temple of Naina Devi before plunging into the lake (Atkinson, 1973). This disastrous event was followed by several hours of incessant heavy rains.

On July 31, 1939 the middle Ayarpatta road passing by Eastleggen and Killarney was breached over a tract of $30 \mathrm{~m}$ in length and $90 \mathrm{~m}$ in height. A major slip occurred in July 1942 below Edwinstowe Cottage while yet another landslip occurred at the precipitous slope of Paansi-Gadhera in 1958.

A disastrous landslip occurred on the Western slope of the Kailakhan spur (outskirts of lake-basin) in 1898. A large pert of the ground slipped down and the water saturated mass of fragmented grey slates moved down as debris flow after it destroyed the old Naini Tal Ranibagh cart road near Birbhatti (Valdiya, 1988). The right bank of Ballia ravine was also ravaged by the mass movements then and again in 1924, a part of the new cart road to Nainital via Chakratta, Manora and Hanumangarhi was practically affected. These landslides along the Ballia ravine can be intimately related to the tectonic activities along the Nainital fault (Fig.2).

\section{Recent Landslide Activities}

It is quite evident from past records that the frequency of landslides has been much less in the past as compared to the recent statistics. Rapid increase in urbanization alongwith the characteristic geographic background has largely added to the danger of landslides and hazards.

The 1987 landslides were monitored over the seven days period of landslide. In this, landslide boulders slipped from the Naina ridge on the morning of 10 September and the process culminated in a large landslide on the night of 13 September uprooting hundred of trees (Fig. 2). The landslides of July 4,
5 and 6 in 1988 caused the maximum damage. On July 6 , boulders, shale and rubble slide to the Melrose and damaged 61 buildings affecting 470 families (Pande, 2006).

The landslide that occurred along the northern flanks of the Snow-view took place on 10 September 1991 and continued till $11^{\text {th }}$ of September. It damaged a few permanent buildings and several temporary huts alongwith the 1880 landslide scar. Once again the area was hit by massive landslide which was preceded by continuous heavy rains in the month of September 1993 (Dates 11, 12). The Staff House area and the buildings situated between the upper and lower Malden road were severely hit by landslip, causing damages and cracks. The severe water flow caused deep erosion on road sides and hill slopes (Fig.3). About 40 meters of upper Mall road approaching the outer part of the Ramlila ground area was damaged. The heavy rains of 11,12 , September 1993 also disturbed the course of a natural spring. Even this area is probably the weakest Zone; the construction activities are still going on adding more to the slope instability. During the rainy season the area is frequently hit by rock-fall and debris flow. Recently in the month of July 29, 1996 about 200 families were affected by rock fall. Towards the southern part of the basin, the Ballia ravine is a very prominent site of landslip because the area lies on a deep fault line. The illegal constructions have added more to the problem of ever-rising stream bed erosion. 1991 onwards the area is suffering from slumping and massive erosion, leading to tilting of houses and trees. On July 12 and 14, 1996, the area experiences a huge landslip causing two deaths and crack and destruction of several dwellings (Geological Survey of India, District Task Force Office, Nainital). The prominent slide that occurred in the recent past was on $17^{\text {th }}$ August 1998 on the Ayarpata hill slopes after heavy rainfall damaged the road part of a Building and the debris material affected a portion of the lake.

The Naina peak slide is active slide, contributing debris at its base and endangering the population of the town. The old land slide debris deposited at the toe of the escarpment is accreting and may slide down. The debris is exposed at a height of approximately $2450 \mathrm{~m}$ below the cliff and extends down of the rim of the lake in the form of a huge 


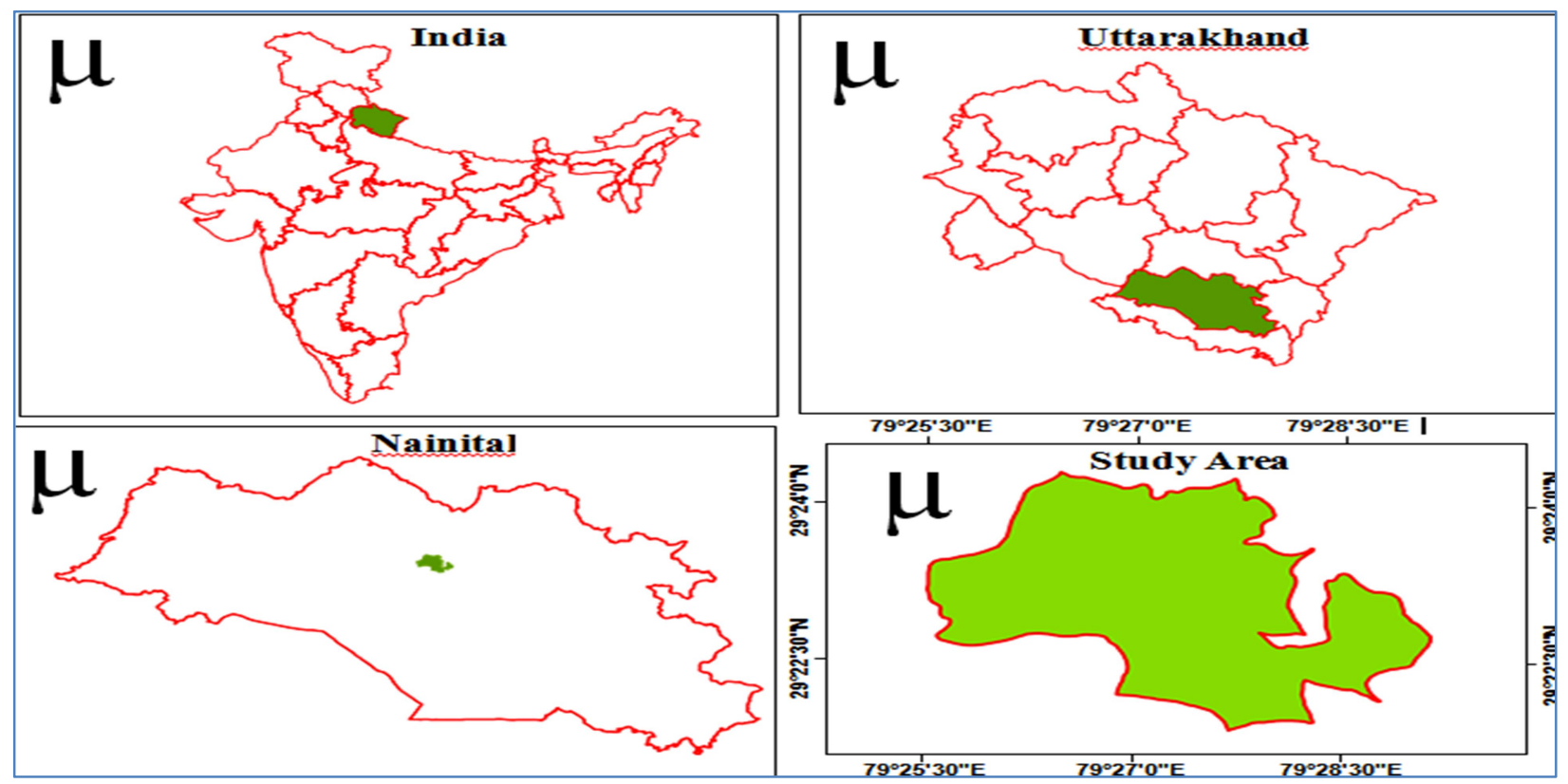

Fig 1. Showing location of study sites

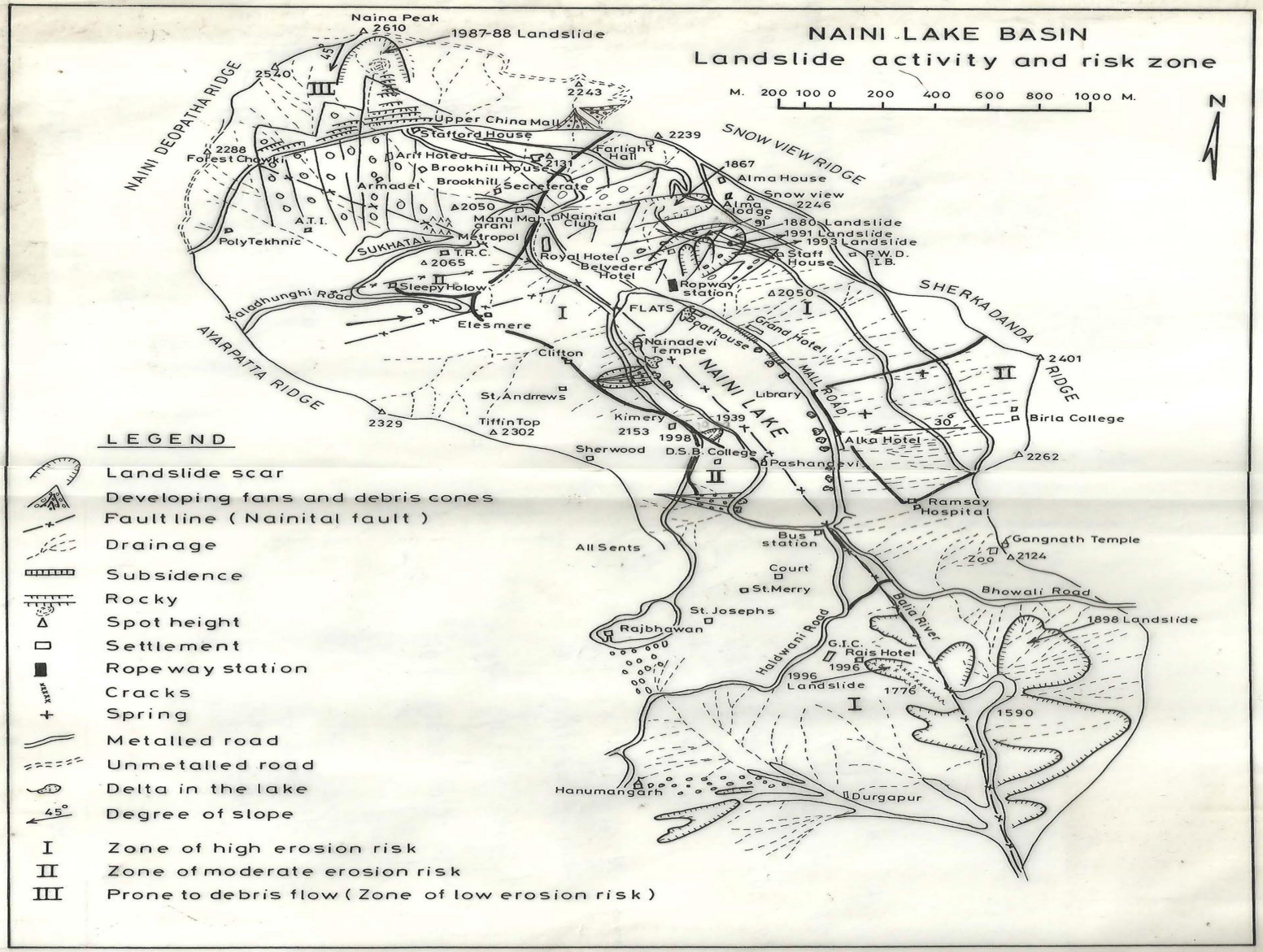

Fig. 2

Fig 2. Tectonic activities along the Nainital fault 


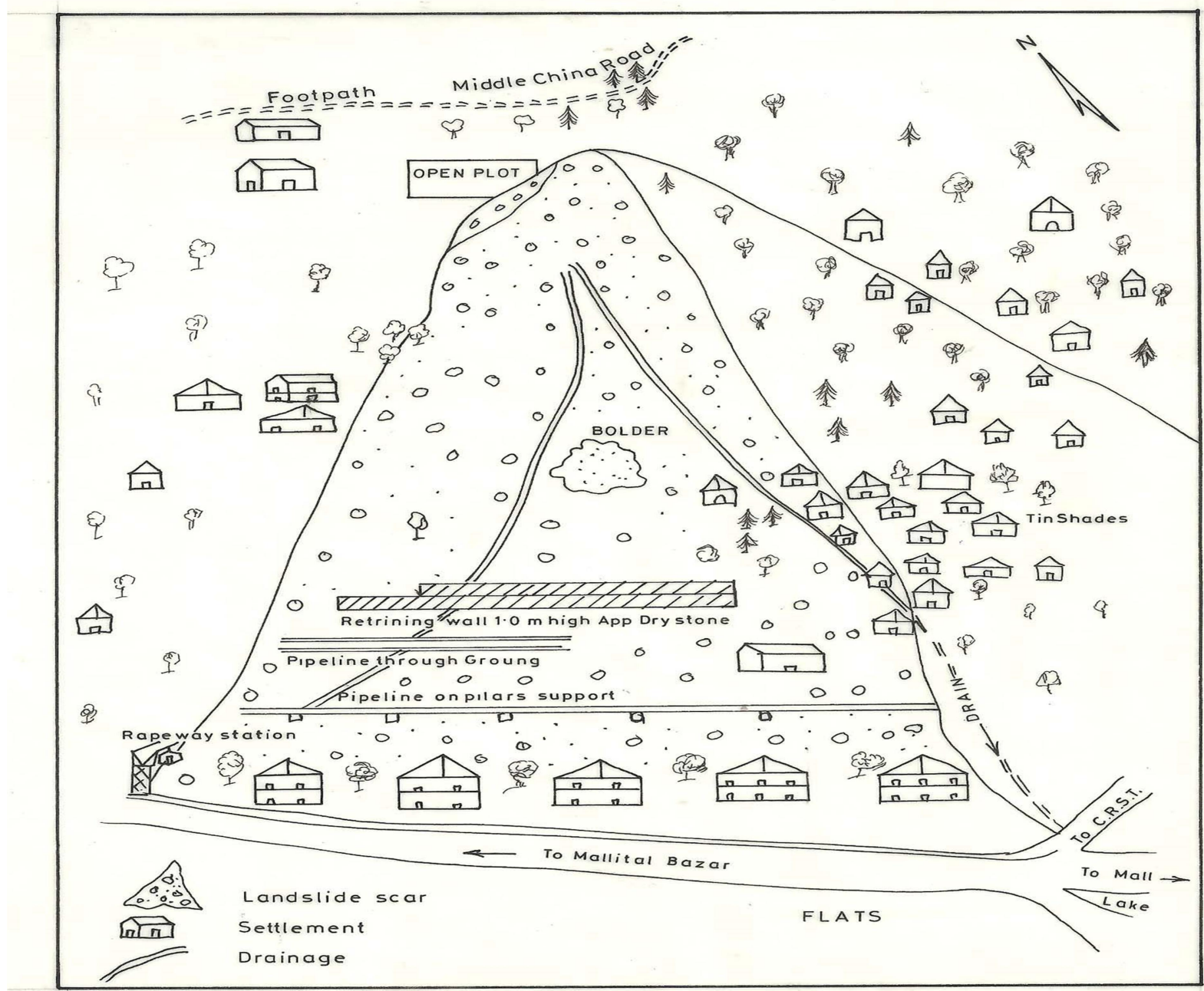

Sketch showing Anthropogenic changes along the active landslide scar ( 1880 landslide zone)

$$
\text { Fig. } 3
$$

Fig 3. Anthropogenic changes along active landslide scar

fan deposit, the part of which is lower reaches in inhabited.

\section{Erosion Intensity and Risk Zoning}

Soil erosion is quite common in the Lake Basin and is the result of removal of vegetation such activities are fairly common in many parts of the town which are prone to accelerated erosion during periods of heavy rainfall and carrying a large amount of silt to the bottom of the lake. We may group such area into the following zones (Fig. 2).

(i) Zone of high erosion risk:

Such areas are invariably associated with recent landscape changes and geological instability. The acceleration of erosion and increased instability of hill slopes are attributable primarily to human activities, i.e., indiscriminate construction of heavy buildings in a much unplanned way. The area encompasses a larger part of the $\mathrm{S}-\mathrm{W}$ facing slope of Sher-ka-danda, Snow-view ridge including Naina peak region and N-E slope of Ayarpatta ridge. The Ballia ravine also falls under the Zones of high unstability. The N-W larger part of Snowview Sher-ka-danda area are much steeper and the Zone is constituted of highly jointed and cleavaged slates of Lower Krol. The second high erosion risk area includes the S-W side of the lake and extreme S-E. The south-eastern area was considerably damaged by landslip in 1939 and 1942 . 
Fortunately, this area has so for a lesser density of buildings and wears a protective canopy of oak forest. The third area of erosion risk includes the upper reaches of Ballia ravine. The stream-bed erosion has caused much movement of landmasses, which is a result of a deep fault lying under the region. The area of landslides is expanding from year to year (Valdiya, 1988).

\section{(ii) Zone of Moderate Erosion Risk:}

The Zone of moderate erosion Risk includes the SE of the Assembly Cottage, D.S.B. Campus area and the lower Ayarpatta ridge. Although these parts are relatively less accessible to growth of settlement but certain construction activities have done a great loss to natural vegetation. As such, these areas have now become the common site of erosion.

\section{(iii) Zone of Low erosion Risk:}

Literally no area of Nainital can be described as a erosion free zone, however the area like Sukhatal, Sleepy Hollow and Ardwell camp can be considered as low risk zone, since the slope is gentler. The intensity of erosion is comparatively much less but the area is exposed to the hazards of rock and debris falls from the higher portions.

\section{Conclusion}

The consequences of different construction activities, steep slopes, heavy rainfall, unstable lithology of this fragile landscape are not only the causes of major landslips but also the continuous land erosion and landslip. Construction activities on the geo-dynamically unstable and faulty zones have aggravated these problems. Not only the natural causes but the human interventions in these areas have added more to theses endemic problems. Thus, precise measures are the need of the hour to protect this fragile land and the surroundings. The recurrent happening of landslides had-affected adversely they physical landscape of the entire Naini lake basin. It can be easily seen as deep creeps and cuts on the faces of most of the hill sides. The huge landslips of the hills of the Snowview, Sher-ka-danda, Naina Deopatta, Ayarpatta and Ballia ravine, had not only affected the surface but also the lithology. Formation of debris fan and the debris flow not only increases the level of siltation in the lake-bed but they have also formed deltas at various points of the lakeside. The cracks along the debris fan raise the erosion level as weaker soil surface is more prone to erosion activity. Besides this road side slumping is also quite common. Moreover, loss of vegetation has added more to the problem since massive landslides cause a great loss of forest cover in the area. In addition to it overall hill and slope instability in the basin is the ultimate threat.

The economic impact of these landslips and largescale erosion can be manifested in losses of lives and several residential buildings and other establishments. Road-slumping is another side effect of massive-erosion. Heavy expenses fare incurred in their reconstruction and maintenance. Moreover at the time of landslides temporary campsites are made for the effected population. These adjustments not only involve greater costs but they also add to the problems of local pollution. The recovery and relief measures not only require appropriate funds but also a lot of attention by the administration. The management personnel and administration officers have to spare much time to attend to these issues at the cost of certain other more important issues of area-development as well as law and order. The government machinery has to bear the opportunity cost of time that could be utilized for some other matters.

\section{Remedial Action Plan}

An ecologically balanced development plan of Nainital town and lake basin is the need of the hour. The plan should aim to help in regeneration of the ecological conditions of Nainital town and its surroundings. Taking into account, the hill slope instability as major geological factor the implementing body/local authority should take following suggested steps:

(a) Hazard zone mapping and demarcation of the zones which are critical in respect of landslides and ground creeping, unsuitable slopes and danger spots,(as shown in fig.2)

(b) Complete ban on blasting for construction of roads and building,

(c) Proper construction of drainage on hill slopes in order to check the velocity of rain water,

(d) Provision of support at critical points along the roads, and around the lake,

(e) Continuous record of movements on critical slopes, 
(f) Repair and increase of the height of the existing catch walls,

(g) Construction of two rows of wire catchments to ensure protection of the densely populated area from the danger of stray boulders.

\section{References}

Atkinson, E.T. 1973. The Himalayan Gazetteer: The Himalayan Districts of North-Western province. Vol. III, Part II. Cosmo Publications, (1973 Reprint) New Delhi, P.40.

Bansal, R.C. and Mathur, H.N. 1976. Landslildes the nightmare of the hill road. Soil Conservation Digest, Dehradun, U.P. 4(1): 36-37.

Bartarya, S.K. and Valdiya K.S. 1989. Landslides and erosion in the catchment of Gaula river, Kumaun Lesser Himalayas, India. Mountain Research and Development, 9(4): 405-419.

Fookes, P.G., Sweeney, M, Mandy, C.N.D and Martin, R.F., 1985. Geological and geotectonical engineering aspects of low-cost road in mountain terrain. Engineering Geology, 21(1): 152

Gupta,V., R.K. Bhasin, A.M. Kaynia, R.S. Tandon, B. and Venkateshwarlu,2016. Landslide hazard in the Nainital city, Kumaun Himalaya, India: the case of September 2014 Balia Nala landslide, Natural Hazards, 80 (2): 863-877.

Kotlia, B.S., Nakayama, K., Bhalla, M.S., Phartiya, B., Kosala, T., Joshi, M., Sanwal, J. and Pande R.N. 2001. Lithology And Magnetic Stratigraphy Of The Lower-Middle Siwalik Succession between Kathgodam and Ranibag, Kumaun Himalaya. Jour. GEOL. SOC. INDIA, 58: 411-423.

Martin, J.H., Rawat, J.S. and Bartarya, S.K. 1989. Environmental indicators of landslide activity along the Kulbury road, Nainital. Kumaun lesser Himalayas. Mountain Research and Development, 9(1): 26.

Pande, R. 2006. "Landslide of Rishikesh-Badrinath National Highway at Devprayag, District Tehri Garhwal, Uttaranchal (India)", Disaster Prevention and Management, 15 ( 2): 256-261.

Rawat, J.S. 1988. Geomorphic outline of NainiTal watershed. Geographical Review of India. Vol. 50, No- 1, March 1988, The Geographical Society of India Calcutta, P.55.

Valdiya, K.S. 1988. Geology and Natural Environment of Naini Tal Hill, Kumaun Himalayas, Gyanodaya Prakashan, Nainital, Pp141-145. 